\title{
The spread of melanoma to the pericardium: Brief history of cellular interest
}

\author{
Wilson I. B. Onuigbo* \\ Department of Pathology, Medical Foundation and Clinic, 8 Nsukka Lane, Enugu 400001, Nigeria
}

\begin{abstract}
Search of the far famed monograph of Willis for the pericardium revealed scanty materials, including the lack of specific mention of melanoma. However, although he usually cited historical materials especially from the Transactions of the Pathological Society of London, none was traceable concerning pericardial melanoma. Accordingly, this paper collates interesting cases from the tangible Transactions.
\end{abstract}

\section{Introduction}

Rupert Willis [1] published a landmark monograph titled "The Spread of Tumours in the Human Body." Since his exemplary use of the Transactions of the Pathological Society of London was to cite historical information, I deem it worthwhile to extract from the Transactions the data for this brief history of melanoma of the pericardium. Meanwhile, it suffices to mention his general statements as metastasis being "an infrequent event" and one that probably follows "permeation of the basal pericardium." Accordingly, let me collate some historical cases chronologically hereunder:

\section{Historical texts}

\section{6-Ogle [2] was expansive as follows}

"Both the pericardium and endocardium, and the substance of the walls, were the seat of deposit, though it was rare in the latter part. Externally, it seemed chiefly to follow the course of the large bloodvessels and lymphatics.

\section{8-Legg [3] was descriptive thus}

The pericardium shows many new growths, both outside and inside; the surface covering the left ventricle shows these nodules most abundantly; there are but few on the right side.

\section{1- Machenzie [4] was persuasive thus}

"The pericardium contains about a teaspoonful of yellow-stained fluid. It is adherent to the left ventricle near the apex by a loose band of fibrous tissue. Under the endothelial covering of the sac, on its inner surface, there is here and there a firm, flattened, circumscribed greyishblack nodule, larger than a split pea."

\section{4-Beadles [5] were almost secretive thus}

"There was another small growth beneath the pericardial covering."

\section{8-Calvert and Pigg [6] were negative as follows}

"The pericardium was everywhere adhensive by membraneous adhesions, which easily broke down." Perhaps, this was added because the heart itself was involved concerning the walls of the auricles, and many from the ventricle, especially near the auriculo-ventricular grove, where some of them were as large as walnut."

\section{Discussion}

We go to the emphasis of the great German Pathologist, Julius Cohnheim, [7] who vouched that Nature's footsteps are traceable with autopsy. Therefore, it is fitting that all the cited cases were from autopsied patients. Perhaps, it is sufficient to add the conclusions arrived at by Godlee [8] as follows:

"In conclusion, I would say that these pigmented tumours, when they fall in our way, are worthy of very careful observation. We are able to detect the first appearance of a new growth in any part, and it is evidently these very minute ones which afford the best opportunity of studying the method of development of this particular disease, and probably of throwing light on the origin and progress of sarcomata in general.

These recommendations turn out to be good omens. This is in terms of the ongoing progress being made in the microscopy of melanoma [9].

\section{References}

1. Willis RA (1973) The spread of tumours in the human body. Butterworths, London58: 186.

2. Ogle JW (1856) Melanotic carcinomatous deposit connected with the dura mater, the lining of the ventricles, and the seventh and ninth pairs of cranial nerves. Trans Path Soc Lond 7: 5-8.

3. Legg JW (1878) Melanotic sarcoma of the eyeball; secondary growths in the organs of the chest and belly, particularly in the liver. Trans Path Soc Lond 29: 225-229.

4. Mackenzie J (1891) Melanotic sarcoma, very widely disseminated. Trans Path Soc Lond 42: 321-329.

Correspondence to: Wilson I. B. Onuigbo, Department of Pathology, Medical Foundation and Clinic, 8 Nsukka Lane, Enugu 400001, Nigeria, Tel: +2348037208680, E-mail: wilson.onuigbo@gmail.com

Key words: cancer; melanoma; pericardium; spread; history

Received: March 30, 2016; Accepted: April 28, 2016; Published: April 30, 2016 
5. Beadles CF (1894) A case of multiple malignant growths. Trans Path Soc Lond 45: 188-197.

6. Calvert J, Pigg S (1898) A case of melanotic sarcoma. Trans Path SocLond 49: 297 299.
7. Cohnheim J (1889) Lectures on general pathology. The New Sydenham Society, London p.14.

8. Godlee RJ (1874)Melanotic sarcoma in the medulla oblongata secondary to a similar growth situated probably in a lymphatic gland. Trans Path Soc Lond 25: 18-23.

9. Kuphal S, Bosserhoff A (2009)Recent progress in understanding the pathology of malignant melanoa. J Pathol 219: 400-409.

Copyright: $@ 2016$ Onuigbo WIB. This is an open-access article distributed under the terms of the Creative Commons Attribution License, which permits unrestricted use, distribution, and reproduction in any medium, provided the original author and source are credited. 